\title{
Helyzetkép az iskolai és iskolán kívüli környezeti szemléletformálásról ${ }^{1}$
}

\author{
Nagy Bence ${ }^{1}$, Persa Mária ${ }^{2}$ és Munkácsy Béla ${ }^{3}$ \\ ${ }^{1}$ ELTE Pedagógiai és Pszichológiai Kar Neveléstudományi Doktori Iskola, \\ ${ }^{2}$ Sashegyi Arany János Általános Iskola és Gimnázium \\ ${ }^{3}$ ELTE Természettudományi Kar Környezet- és Tájföldrajzi Tanszék
}

\begin{abstract}
Absztrakt
Egyre mélyülő környezeti válságba sodródunk. A problémák egy része már nem elkerülhető, de mérséklésükben a pedagógusoknak igen nagy szerepük kellene legyen. Ugyanakkor az ezzel kapcsolatos esetleges felismerés nem alakítja egyformán a szemléletformálás lehetőségeiről alkotott vélekedésünket. E helyzet feltárására egy online kérdőíves felmérés szolgált, amelynek kitöltésében 256 magyar pedagógus vett részt. Az elemzés során kiderült, hogy túlnyomó többségük fontosnak tartja, hogy tanóráin környezettudatosságra való nevelés és szemléletformálás is történjen. A szaktanárok személyes példáin keresztül bizonyítható, hogy bármely szaktantárgy órai keretein belül van lehetőség a környezettudatosság fejlesztésére - ezt a kitöltők kitüntetett többsége fontosnak és a pedagógusoktól elvárhatónak is tartja. Tízből kilenc alkalmazott már ilyen jellegü specifikus feladatokat az óráin, viszont csak tízből három vett részt az iskolán kívüli programokban, szervezőként vagy támogatóként a témakörben. Azok, akik nem alkalmaznak ilyen módszereket, elsősorban ismeret-, idő- és erőforráshiányra hivatkoznak, illetve többek szerint az efféle „külsős” programok szervezése nem tartozik a feladatai közé. Ugyanakkor a szakirodalmi források rámutattak arra, hogy az iskolán kívüli programok segítik a diákok elméleti ismereteinek gyakorlatban történő alkalmazását, és olyan kulcsélményeket szerezhetnek, melyek nagyban hozzájárulnak szemléletük formálásához.
\end{abstract}

Kulcsszavak: fenntarthatóságra nevelés, iskolai szemléletformálás, iskolán kívüli környezeti nevelés, oktatáskutatás

\section{Bevezetés}

A tanulmány írói földrajztanárok. Egyetértenek abban, hogy tanárként valamelyest kirakatemberekké, mintákká váltak, azaz hatással vannak a diákjaikra, nem csak szavaikkal, hanem cselekedeteikkel is. Mindez nyilván a pedagógus társadalom szélesebb körére is általánosítható: a diákok megfigyelik

\footnotetext{
${ }^{1}$ A tanulmány az Innovációs és Technológiai Minisztérium ÚNKP-19-2 kódszámú Új Nemzeti Kiválóság Programjának szakmai támogatásával készült.
} 
viselkedésünket, tetteinket, így akaratlanul is hatással vagyunk rájuk, mintáinkat beépíthetik, elsajátíthatják. Számukra tanárok vagyunk a boltban, amikor láthatják, hogy mit és hogyan vásárolunk, tanárok vagyunk a buszon, mielőtt az iskolába érkezünk, és akkor is, amikor a joghurt elfogyasztása után, egy óvatlan mozdulattal kidobjuk a müanyag edényt a kommunális hulladékba. Akár egyetlen cselekedet, egyetlen mozdulat, is mélyen bevésődhet a diákjainkba. Nehéz hitelesnek maradni a környezet- és természetvédelem témakörében, nemcsak tanárként, de szülőként is, hiszen az elsődleges szocializációs közeget mégiscsak az otthon, a szülők jelentik (Zrinszky, 2002). Ez súlyos felelősség, és meglehetősen riasztóan hangzik, sokakat esetleg elbátortalanít, de nap mint nap meg kell vívni a csatákat - sokszor saját magunkkal szemben is. A környezet védelme a család szintjén sem csupán pillanatnyi teljesítmény, hanem egy hosszútávú, következetes munka, amely a mai világban elengedhetetlenné vált. Nálunk sem megy minden tökéletesen, ahogy valószínűleg egyik háztartásban sem. Nem célunk, hogy bárki feje fölött pálcát törjünk, éppen ellenkezőleg. Érezzük a mindennapok nehézségeit a diákok között, ezért egy több éve folyó kutatás felismerései alapján szeretnénk támpontokat adni a tekintetben, hogy hogyan lehet érzelmi, gondolkodási és tapasztalati úton kialakítani és belsővé tenni számukra a környezetközpontú gondolkodást, hogy ezáltal egymás mintái és példái is lehessenek.

\section{Klímavészhelyzet}

2019. november 5-én a Fővárosi Közgyűlés érdemi határozatot hozott, amelyben deklarálták, hogy klímavészhelyzet van, hiszen az antropogén eredetü éghajlatváltozás már a jólétet, a békét és a következő generációk életkörülményeit veszélyezteti (Rockström, Steffen \& Noone, 2009). 2019. november 28-án az Európai Parlament az egész Európai Unióra kiterjedően kihirdette a klímavészhelyzetet, amelyből nehéz más következtetésre jutni, mint arra, hogy valóban nagy a baj. Ugyanakkor a megoldások kapcsán eltérőek a vélemények: az atomenergia alkalmazása egyes gazdasági körök szerint jó megoldás, ám a statisztikák világosan igazolják, hogy a csernobili baleset óta a fejlett gazdaságok és demokráciák egészen más irányba mozdultak el.

Az új irányt a helyben elérhető megújuló energiaforrások jelentik, ezernyi alkalmazásuk számos területen hozott már forradalmi változásokat napjainkra is. Ugyanakkor klímavédelmi szempontból ezek a technológiák sem egyenértékűek, illetve sok országban - így hazánkban is - a térnyerés üteme sem kielégítő. Ugyanez a probléma az energetikai hatékonyság javításával, vagy a szükséges strukturális és szemléletbeli változások tempójával. Ráadásul könynyen alakulhat ki bennünk egy olyan hamis kép, mintha mindezen bonyolult folyamatokban mi magunk kívülállók volnánk, ezekre nem volna ráhatásunk.

Ha nem is vagyunk egyformán felelősek a kialakult helyzetért, mindnyájan a saját bőrünkön érezzük az éghajlatváltozás hatásait. Védhetjük magunkat azzal, hogy az ipar sokkal jelentősebb kibocsátó, mint a lakosság, vagy, 
hogy az Egyesült Arab Emírségekben élők ökológiai lábnyoma sokszorosa egy átlag magyarországi lakosénak (Mogyorósi, 2018.) - ám a várható következmények ismeretében ennek kevés értelme van. Értelmiségiként különösen nagy a felelősségünk. Például minden vásárlásunkkal szavazunk valami mellett és másvalami ellen (Johnson, 2016), az ipar pedig csak annyit tesz, hogy létrehozza mindazt, amire igény van - igaz, hogy mindeközben az igényeink befolyásolására is törekszik. Ha a környezetbarát termékek iránt nőni fog a kereslet a nem környezetbarát termékek rovására, akkor azt a kínálat is követni fogja (Yilmaz, Majcen, Heidari, Mahmoodi, Brosch \& Patel, 2019) - ez a döntéshozók súlyos felelősségét is felvillantja, hiszen a gazdasági és jogi szabályozás eszközei, amelyek révén ez a folyamat felgyorsítható, az ő kezükben vannak.

A tudományos világban már nincs arról vita, hogy az éghajlatváltozás valós, és sürgősen kezelendő probléma, de még így is vannak, akik szerint nem is létezik. Ám a klímaszkepticizmus szerencsére nem széles körben elterjedt jelenség (Poortinga, Spence, Whitmarsh, Capstick \& Pidgeon, 2011) - ugyanakkor kijelenthető, hogy a háttérben legtöbbször a természettudományos műveltség és a hiteles hírforrások ismeretének hiánya áll, míg a döntéshozatalt gyakran rövid távú gazdasági érdekek befolyásolják.

Egyes kutatók - például Hamilton (2015) - már egyenesen új földtörténeti korszaknak, azaz antropocénnek nevezik korunkat, melyben az ember kezdi teljesen és egyúttal visszafordíthatatlanul átformálni a földi ökoszisztémát. Vannak olyan kutatások is, melyek szerint fel kell készülnünk az alkalmazkodásra, és meg kell tanulnunk, hogy hogyan élhetünk az összeomlásközeli instabil helyzetben (Benson \& Craig, 2014; Foster, 2015). Születtek olyan tudományos munkák is, melyek egyértelmüen a jelenlegi gazdasági és társadalmi rendszer összeomlását vetítik előre (Bendell, 2018).

\section{Tanári felelösség}

Ebben a helyzetben különösen nagy szükség van arra, hogy az oktatásból, bármilyen jellegü is, a lehető legtöbbet hozzuk ki. Ebben az oktatással kapcsolatos kutatási tevékenység nyújthat fontos támogatást. Az angliai Nottingham Egyetem kutatói összehasonlítást végeztek arról, hogy a diákok mennyire vannak tisztában az éghajlatváltozással, és annak folyamataival, következményeivel (Oliver \& Adkins, 2020). A kutatásban 54 ország PISA adatai szerepeltek, köztük Magyarországé is. A lista élén Svédország és Portugália helyezkedik el, a diákok ezen országokban a leginkább informáltak a klímaváltozással kapcsolatban. (1. ábra) A térkép azt mutatja be, mennyi a valószínűsége, hogy a diákok a képzés során légköri üvegházgázokkal kapcsolatos információkkal találkoznak. Minél világosabb a szín, a valószínűség annál nagyobb, tehát a diákok a citromsárgával jelölt területeken találkoznak átlagosan a legtöbbet ezen információkkal. 




1. ábra

A légköri üvegházgázokkal kapcsolatos tájékozottság országos arányban a 15 éves korosztályban (Oliver E Adkins, 2020)

Ennek oka lehet, hogy ezek az országok klímasemlegességre törekednek 2050-re, így nem csak az oktatásban, de a politikában és a médiában is megjelenik ez a problémakör. A magyar diákok ugyanezen listán közelebb állnak a legrosszabbul teljesítő Amerikai Egyesült Âllamokhoz, mint az európai átlaghoz. Mivel a politika és a média is igen kevéssé segíti a tudásátadást a témában, lényegesen nagyobb szerep és felelősség hárul az oktatásra. Kulcsfontosságú volna, hogy a Nemzeti Alaptanterv, illetve kerettantervek is kiemelten kezeljék a témakört, de a legutóbbi „reform” ismét a természettudományok jelentőségének csökkenését eredményezte. A környezeti válságra való felkészítést nem segíti az alsó tagozat első két évfolyamából a környezetismeret száműzése, de megbocsáthatatlan hiba a felsőbb évfolyamokban az óraszámok csökkentése és az elvont ismeretanyag is. Ebben - az akár drámainak is nevezhető - helyzetben különösen fontos a tanárok példamutatása, valamint a direkt és indirekt fejlesztés, amelyek az elsődleges színterei a fenntarthatóságra és környezeti felelősségvállalásra való nevelésnek.

Egyre fontosabbá válik tehát az a kérdés, hogy milyen mértékben vagyunk képesek ezeket a témákat és ismeretelemeket bevinni a szaktárgyi órákra vagy integrálni az egyéb iskolán belüli tevékenységekbe - ugyanakkor az iskolán kívüli terepi programok jelentőségét sem szabad alábecsülni. Mindezeknek a hazai gyakorlatban való megjelenését egy kérdőíves felmérésre alapozott kutatás keretében vizsgáltuk. 


\section{A kutatás bemutatása}

\section{Méröeszköz}

A felmérés online kérdőívvel, anonim, önkitöltős módszerrel, keresztmetszeti kényelmi mintavétellel történt. A kitöltés ideje hozzávetőlegesen három-öt perc volt. A kérdőív első felében a pedagógusok születési évét, tanítással töltött éveiknek számát, tanított szaktárgyaikat, továbbá iskolájuk típusát (melyben jelenleg is tanítanak) kérdeztük. Ezután két darab, ötfokú skálán mérő kérdés következett, ahol az 1 az Egyáltalán nem tartom fontosnak az 5 a Kiemelten fontosnak tartom opció volt. Az első kérdés Mennyire tartja fontosnak, hogy a szaktárgyi óráján környezeti szemléletformálás is történjen?, a második kérdés pedig Mennyire ért Ön egyet azzal a kijelentéssel, hogy bármely tantárgy keretein belül van lehetöség a környezetvédelmi szemléletformálásra?. A második kérdés esetében az 1 jelentése szintén Egyáltalán nem értek egyet az 5 jelentése pedig Teljes mértékben egyetértek volt. Ezután két, szöveges választ igénylő kérdést kellett kitölteni a kutatásban résztvevőknek: Alkalmaz-e Ön az óráin bármilyen módszert, vagy részt vesz-e iskolán belüli környezetvédelmi szemléletformáló programok szervezésében, megvalósitásában? illetve, Alkalmaz-e Ön az óráin, vagy részt vesz-e iskolán kívüli környezetvédelmi szemléletformáló programok szervezésében, megvalósitásában?. Ezekre a kérdésekre először egy Igen vagy Nem választ lehetett adni, majd mindkét esetben kértük az adott válasz részletes, szöveges indoklását.

\section{Minta}

A kérdőívet 2019.11.13. és 2019.11.28. között összesen 256 fö töltötte ki. Az adatok feldolgozása során nem kellett válaszadókat kizárni rossz válaszok, súlyos adathiány vagy látható adatismétlés miatt, így a feldolgozott adatok száma a kitöltőkkel megegyező. A 2. ábrán látható, hogy a kitöltő pedagógusok a tanítási évek alapján nagy szórást mutatnak, a mintában mind a tapasztaltabb, mind a pályakezdő pedagógusok megfelelő arányban vannak jelen. A kutatásban résztvevő pedagógusok átlagéletkora 47,44 év volt, amely csak igen kis mértékben (0,56 évvel) tér el az Gazdasági Együttműködési és Fejlesztési Szervezet (OECD) 2018-ban publikált nagymintás kutatásában leírtaktól (OECD 2018). Területi eloszlás szempontjából kérdéses a minta reprezentativitása, a kutatásban ez a szempont nem jelent meg. 


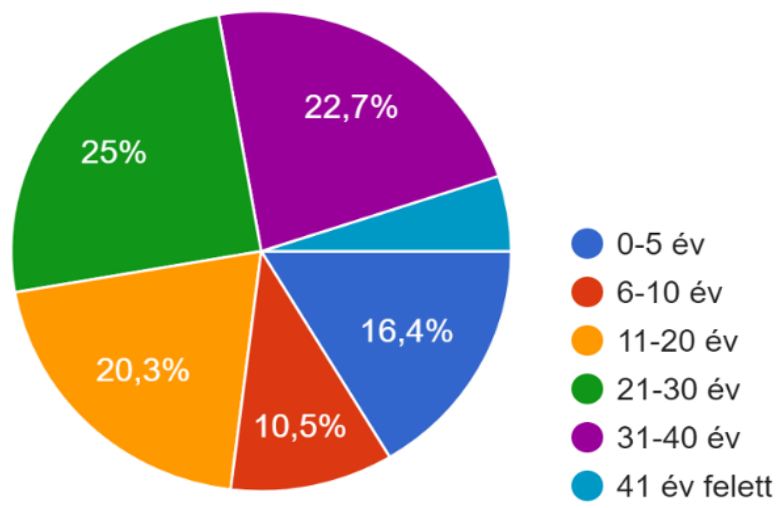

2. ábra

A felmérést kitöltő pedagógusok megoszlása tanitási évek alapján

A kapott adatokból kiolvasható, hogy az általános iskolában tanítók a kitöltők között 45,29\%-ban (130 fö); a gimnáziumi tanárok 30,66\%-ban (88fö); a szakgimnáziumi tanárok 14,28\%-ban (41fö); a szakközépiskolákban oktatók 7,3\%-ban (21 fö); alapfokú művészetoktatási intézményben órát adók pedig 2,4\%-ban ( 7 fö) voltak jelen.

Az adatokat szemlélve látható, hogy a kitöltők számának összege eltér a felmérésben résztvevő 256 főtől. Ennek oka, hogy több pedagógus tanít párhuzamosan más-más képzési szinteken. Szaktárgyak tekintetében a következőképpen alakultak az arányok:

- nyelvtanárok (benne magyar nyelv és irodalom, angol, német, olasz, orosz, spanyol, latin, portugál) 48\% (124 fö);

- természettudományos tárgyakat tanítók (biológia; fizika; kémia; földrajz; természet- és környezetismeret; komplex természettudományok) 38\% (98 fö);

- matematikatanárok 19\% (46 fö);

- történelemtanárok 10\% (26 fö);

- informatikatanárok 8,5\% (22 fö);

- testneveléstanárok 6\% (16 fö);

- tanítók 6\% (16 fö);

- egyéb szakterületek, amelyek kevesebb mint 10 fővel képviseltették magukat a kutatásban (pszichológia-, társadalomismeret-, ének-, etika-, filozófia-, technika-, média-, rajz-, szakmai- és fejlesztőtanárok), mindöszszesen 64 fö. 
Az adatok összege és százalékos aránya ismételten eltér a 256 főtől, mert a kérdőívet egy- és többszakos tanárok is kitöltötték, így a fent jelölt bontásban egy tanár többször is szerepelhet. A fentiek azt mutatják, hogy a felmérésben a tanárok széles közösségétől kaptunk válaszokat, így a szerzett információkból kiolvasott következtetések sok szempontból megalapozottnak tekinthetők.

\section{Az eljárás menete}

A kérdőív kitöltője szaktól, tanítási tapasztalattól, foglalkoztatási formától és iskolatípustól függetlenül bárki lehetett, aki pedagógiai munkakörben dolgozik. A kitöltők toborzása tanárkollégák célzott megkeresésével, továbbá a kitöltési felhívás közösségi oldalakon történő megosztásával történt. Így potenciálisan több ezer pedagógushoz juthatott el az ürlap, az ország teljes területén. Ezen felül segítséget kaptunk Székesfehérvár Megyei Jogú Város Önkormányzatától is a kutatás Fejér megyében történő népszerüsítésében.

\section{A kutatás eredményei}

A kitöltő tanárok több mint $88 \%$-a fontosnak vagy kiemelten fontosnak tartja, hogy a szaktárgyi óráin is történjen környezeti szemléletformálás. (3. ábra) Az ötfokú skálán adott pontok átlaga erre a kérdésre 4,5 pont volt. Ez az eredmény abból a szempontból is pozitív, hogy a kérdőívet bármely, a tanárképzésben tanulható szakkal rendelkező tanár kitöltötte.

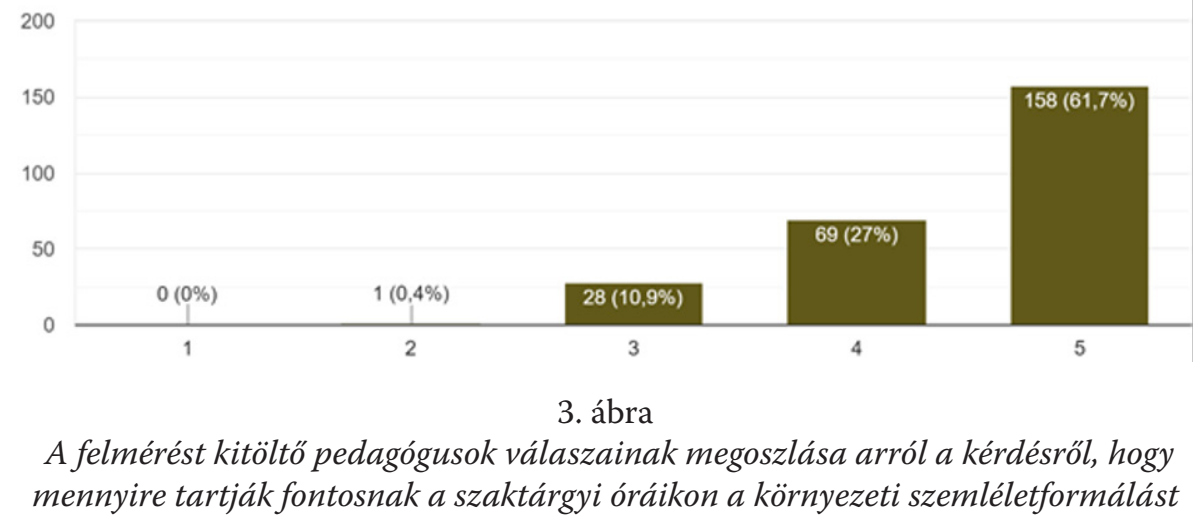

Szakirodalmi adatok alapján (Bella et al., 2013) a pedagógusok minimum kettő, maximum négy évig tekinthetők pályakezdőnek. A pályakezdők és a tapasztaltabb tanárok vélekedése eltérhet, ezért az ötfokozatú skálán adott válaszokat aszerint is külön választottuk, hogy az illető tanárok hány éve vannak a pályán. Ennek eredménye, hogy a 0-5 éve és a 6-10 éve tanítók 
válaszainak átlagértéke 4,33 és 4,37. A 11-20, 21-30 és 31 év felett tanítók esetében ez az érték 4,53; 4,59 és 4,54. Ha pedig az öt évnél kevesebb időt és öt évnél több időt tanító tanárokat hasonlítjuk össze, akkor az átlag 4,33 és 4,51. Az látható, hogy - bár a különbség nem szignifikáns - a régebb óta tanító tanárok a szaktárgyuktól függetlenül némileg fontosabbnak tartják, hogy a tanóráikon a környezetvédelemmel és globális problémákkal is foglalkozzanak. Ennek a jelenségnek a miértjére egy kontroll méréssel, fókuszcsoportos beszélgetésekkel és specifikusabb vizsgálatokkal lehetne választ adni. A háttérben az is állhat, hogy a kerettantervek által elvárt tananyagok mennyisége meglehetősen nagy, ezért a kisebb tapasztalattal rendelkező tanárok még nehezebben tudják ezt beosztani, így kevésbé bátran visznek be a kerettantervben - sajnálatosan - nem elvárt témákat és aktualitásokat. Egy michigani általános iskolák körében végzett hasonló kutatásban (Forbes \& Zint, 2010) szintén megjelenik, hogy statisztikailag jelentős az összefüggés a tanítási tapasztalat és aközött, hogy saját bevallásuk szerint mennyi időt töltenek a tanárok az órán természetvédelmi kérdések tanításával. A kutatás a tanárok önértékelésére vonatkozó kérdéseket is tartalmaz, melyek rámutatnak arra, hogy a tapasztaltabb tanárok inkább gondolják úgy, hogy megvan a tudásuk ahhoz, hogy természetvédelmi kérdésekkel foglalkozzanak, szemben a gyakorlatlanabb tanárokkal.

Bizakodásra adnak okot környezeti szemléletformálásnak egy adott tantárgyhoz való rögzítésével kapcsolatos nézetek. Egy ötfokú skálán kellett véleményt nyilvánítani arról, hogy mennyire értenek egyet azzal az állítással, hogy bármilyen tantárgy keretein belül van lehetőség környezeti szemléletformálást megvalósítani. (4. ábra) A kitöltők több mint 90\%-a részben vagy teljes mértékben egyetértett egy nyitottabb megközelítéssel: a pontszámok átlaga 4,63 pont lett. Érdemes itt is megvizsgálni, hogy erről az állításról miként vélekednek a kitöltők aszerint, hogy hány éve tanítanak. A legalacsonyabb pontszámátlagot (4,48 pontot) ismételten a 0-5 éve tanító pedagógusok válaszai adták, az átlaghoz képest magasabb értékeket a 30 évnél régebb óta tanítók 4,68 pontot, pályakezdő és tapasztalt pedagógusok összehasonlításában pedig 4,48 és 4,66 ez a pontszámátlag-arány. Magyarázatként itt is a fiatalabb tanárok túlterheltségét és kevesebb tapasztalatát tudnánk megjelölni, azzal a kitétellel, hogy az átlagtól való eltérés nem nagy, így nem ad okot aggodalomra. 


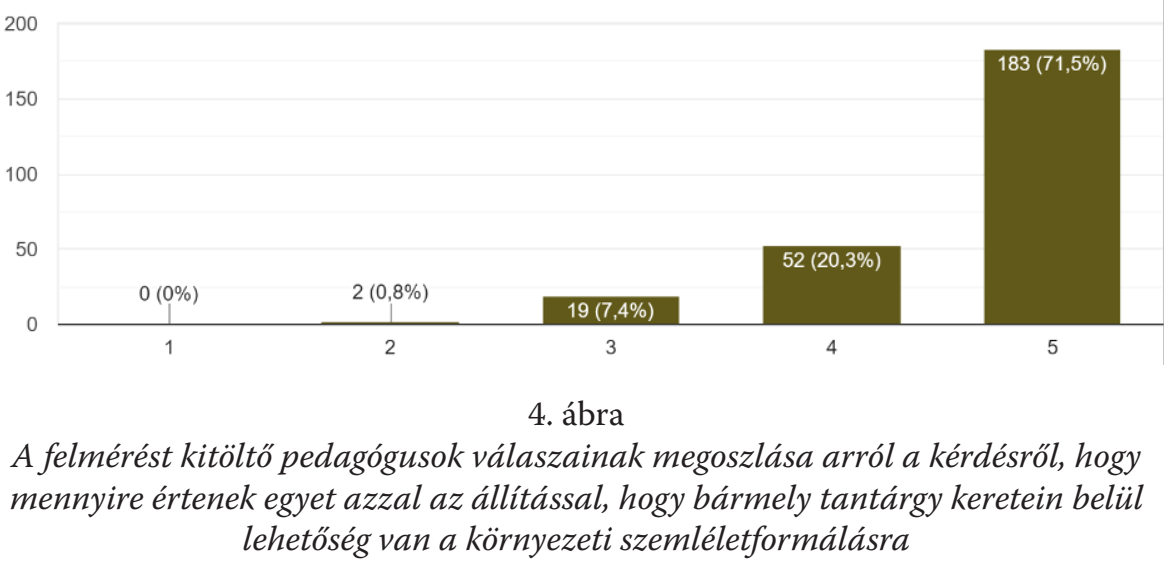

A fentiek rámutatnak arra is, hogy a kitöltő pedagógusok egyetértenek a 2012-ben elfogadott, a Nemzeti Alaptantervben is megfogalmazott alapelvvel és fejlesztési céllal, mely szerint minden pedagógus feladata a fenntarthatóságra és környezettudatosságra való nevelés, és a környezetért érzett felelösségtudat kialakítása (NAT, 2012). Ez teljes összhangban áll azzal a kijelentéssel, hogy a fenntarthatósági nevelés „nem lehet egy tantárgyhoz kötött, hanem csak a tantárgyakon átnyúló, a környezeti problémákat felismertetö, mindenekelött együttmüködést, részvételt kivánó tanitási tanulási tevékenység”' (Csenger, 2015. p. 182).

Ugyanakkor megemlítendő az is, hogy a módosított, 2020. januárjában a Magyar Közlönyben megjelent, és 2020 szeptemberében bevezetett módosított Nemzeti Alaptantervben már nem szerepel kulcskompetenciaként a természettudományos- és technikai kompetencia (NAT, 2020), holott napjainkban ez még inkább fontos témakör a felnövekvő generáció számára. Jelen helyzetben csak abban bízhatunk, hogy a tanárok a szabályozási környezet kifejezetten hátrányos változása ellenére továbbra is fontosnak tartják és meg is valósítják a természettudományos szemléletformálást.

Pozitívumként értekelhető, hogy a kitöltő tanárok túlnyomó többsége, 87\%-a alkalmaz tanórái során olyan specifikus feladatokat, melyeknek célja a fenntarthatóságra nevelés és környezeti szemléletformálás. (5. ábra) A pályakezdők $85 \%$-a, míg a tapasztaltabb tanárok $88,15 \%$-a alkalmaz saját bevallása szerint óráin specifikus feladatokat vagy módszereket. Itt azonban megemlítendő, hogy a kérdőívben nem szerepel kérdés azzal kapcsolatban, hogy a kitöltők pontosan mit értenek a fenntarthatóságra nevelés, a környezettudatosság, illetve a környezet- és természetvédelem fogalmain. Ezek tisztázására való igény már csak a kutatás lezártával merült fel, így ezzel kapcsolatos megállapításokat levonni sajnos nem tudunk. 


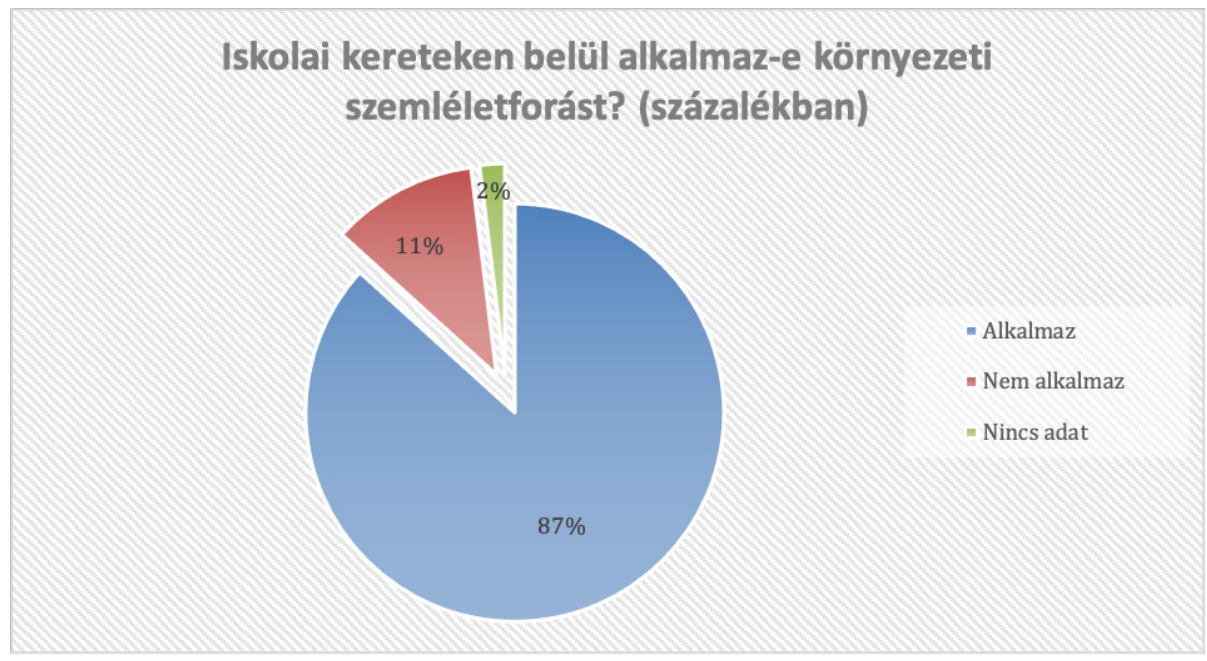

5. ábra

Pedagógusok válaszainak megoszlása arra a kérdésre, alkalmaznak-e iskolai kereteken belül környezeti szemléletformálást

A továbbiakban ezekből szeretnénk bemutatni néhány módszert, melyet már sikerrel alkalmaznak a kitöltő tanárok, ami ötletadó, esetleg átvehető lehet mások számára is:

- magyar nyelvtan: „Olyan szövegértési feladatokat adok, amelyek környezetvédelmi témákról szólnak. Ervelés gyakorlásánál a témával kapcsolatos érvek megfogalmazása és előadása."

- magyar irodalom: „Olyan müveket veszünk, amelyek rámutatnak az élhetö környezet létfontosságára, és példásan szelektiven dobom kukába a szemetet a diákok elött."

- történelem: „...az emberi tevékenység környezetre gyakorolt hatásának tanulmányozása az adott kor képi, vagy szöveges forrásainak elemzésével.” „A vonatkozó tananyagtartalmaknál beszélünk róla (például Ipari forradalmak, migráció stb.)."

- angol nyelv: „Rengeteg anyag, nyelvkönyv foglalkozik szerencsére környezetvédelemmel, és tétel is érettségin, igy nyelvoktatás keretében szerintem sok alkalom nyílik megvitatni a témát, új ismereteket tanitani ezzel kapcsolatban."

- német nyelv: „Nyelvtanárként könnyü dolgom van, a német nyelvkönyvek fontos témája az Umwelt. Hosszú évek során nagyon sok, mindenféle nyelvi szinten használható anyagom gyült össze. Vita, érvelés, játékok... a gyerekek pedig élvezik a témát." 
- spanyol nyelv: „Órán vitatémaként, beszélgetések témájaként újra és újra visszatér, akkor is, ha más témából indulunk ki (gazdaság, lakókörnyezet, életvitel, táplálkozási szokások stb.). Ezáltal érzékelik a diákok, hogy ez nem egy különálló dolog, hanem minden mindennel összefügg, átszövi az életünket."

- mérnöktanár: „Óráimon az aktuális témánál kitérek a környezetvédelmi szempontokra. Például a számítógépek «kidobása», NYÁK (nyomtatott áramkör) készitésénél a vegyszerek kezelésére, és környezeti hatására. Felhívom a figyelmet a takarékoskodásra."

- földrajz: „Az órákon rendszeresen ebből a szempontból vizsgálódunk. Nincs külön módszer, átszövi az egész órát, évet ez a szemlélet."

- alsó tagozatos tanító: „...tantárgyi integráció során, az aktuális környezettel kapcsolatos hírek értelmezése, környezetvédelemmel kapcsolatos filmek megtekintése, szelektiv hulladékgyüjtés bevezetése és ismertetése."

- informatika: „...témanapon a kommunikációs témában számitógéppel támogatva tanulói kérdöív kitöltése, majd elemzése; csoportmunkában különbözö témakörökben kutatómunka, projekt készitése; a településen feltárni a problémás közösségi tereket."

- Waldorf-gimnázium, biológia-kémia szak: „Napenergia-hasznositással foglalkozó, és a hulladékgazdálkodással foglalkozó projektem is volt, mindkettö két hetes volt. Gyakran beszélgetek erröl a diákokkal, és a tananyagba is beépitem."

- biológia: "Szerencsére a biológia órák alkalmával sok lehetöségem van a szemléletformálásra. Szoktam kérni a diákokat, hogy az óra elsö néhány percére, gyüjtsenek híreket, amelyek az órához-témakörhöz kapcsolódnak, ott gyakran elöjönnek környezetvédelmi témák. Maga az ökológia témaköre, állat- és növénytan, mind mind szintere lehet egy vitának, kiselöadásnak, vagy projektmunkának."

- életvitel: „Direkt módon: udvaron, tankertben komposztálás, növénygondozás; kézmüves foglalkozások során: újrahasznositás felhasználható anyagoknál; és szelektív hulladékgyüjtés. Indirekt módon különféle elöadások, projektmunkák, akadályversenyek."

- testnevelés: „Természet megszerettetésén keresztül annak értékének növelése a diákok szemében. - táborok, kirándulások szervezése. Szelektív hulladékgyüjtés kihangsúlyozása. Sok beszélgetés és példamutatás."

A kitöltők túlnyomó többsége szerint valóban van lehetőség bármilyen szaktárgy keretein belül direkt, vagy indirekt módon a fenntarthatósággal és a környezettudatosságra való neveléssel foglalkozni. Egyértelmü cél, hogy a diákokban olyan pozitív, a környezettel és természettel kapcsolatos szemléletmód alakuljon ki (Csenger, 2015), amely révén megtapasztalják, hogy a környezet- és természetvédelem kiemelten fontos területe az életünknek.

Tanulságos annak bemutatása is, hogy a pedagógusok mivel indokolják azt, ha nem alkalmaznak a tanítás során ilyen módszereket. 
- „Csak a tanterv elöírásait alkalmazom, és szerintem nem kell problémázni ezzel a témával."

- „Nincs rá idö. Nagyon szoros a tanmenet."

- „Időhiány miatt, nem tudtam még felkészülni erre a nagyon fontos feladatra."

- „Engem más program jobban vonz. Ennek van az iskolában felelöse, aki jól is csinálja, így én nem kontárkodom ebbe bele."

- „Nekem más feladataim vannak az óráimon” - írta egy természettudományos tanár

Ebben a felsorolásban olvashatóak a leggyakrabban leírt válaszok (idő- és kapacitáshiány, illetve a tantervi kötöttség), továbbá néhány egyedi indok is. Ugyanezen indokokra való hivatkozást találhatunk egy Hong Kong iskoláiban végzett vizsgálat során is (Chi-chung Ko \& Chi-kin Lee, 2003), tehát elmondható, hogy ezek a problémák nem csak hazánkban vannak jelen a tanárok életében.

A fenti, iskolai munkához szorosabban kapcsolódó felvetéseket érdemes összevetni az iskolán kívüli oktatási-nevelési projektekre irányuló kérdésekkel. A kitöltők önbevallása alapján, eddigi tanári munkája alatt iskolán kívüli programot csupán 32,5\% alkalmaz, támogat, vagy vesz részt benne, míg 64\%-ukra ez nem jellemző, 3,5\% pedig nem válaszolt erre kérdésre. (6. ábra) A pályakezdők 26,85\%-a, míg az 5 évnél régebb óta tanító tanárok 30,09\%-a adott "Igen" választ.

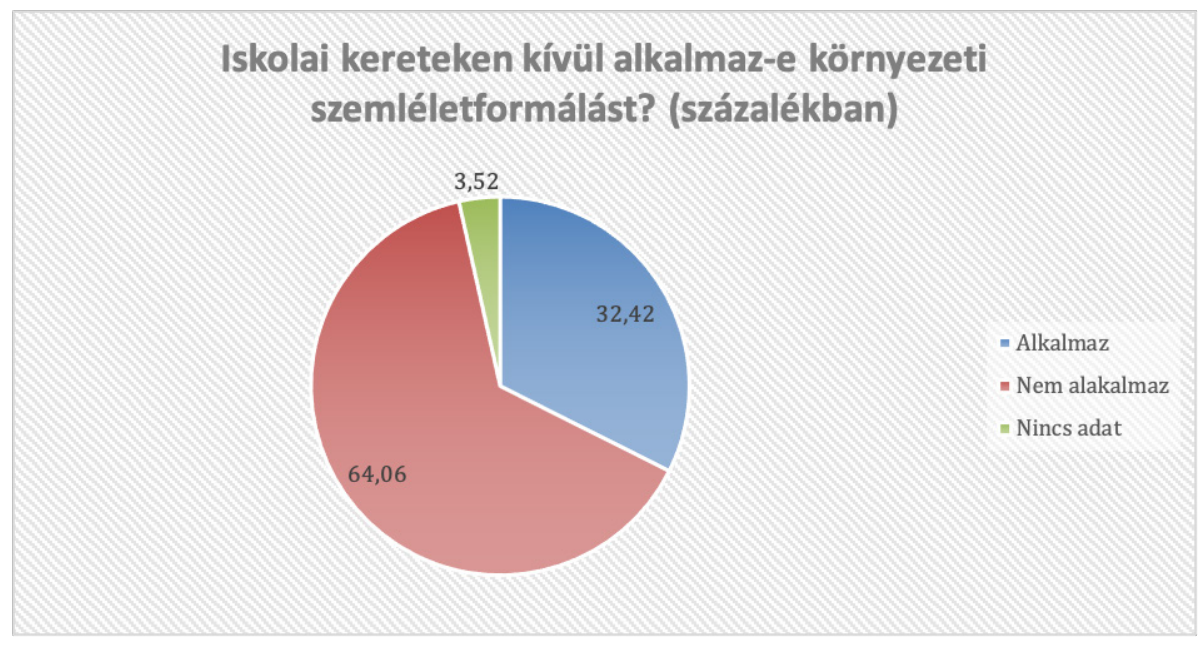

6. ábra

Pedagógusok válaszainak megoszlása arra a kérdésre, alkalmaznak-e iskolai kereteken kívül környezeti szemléletformálást 
Az iskolai kereteken kívüli programokhoz a legtöbb esetben tanulmányi kirándulás és terepgyakorlat szervezését adták válaszként. Ezt követték a tematikus táborok és erdei iskolai programok. Nagy számban jelölték meg a közös szemétszedéseket is. Több esetben csatlakoztak a „TeSzedd” mozgalomhoz, illetve volt olyan válaszadó is, aki az iskolájában a diákjainak és azok családjainak bevonásával rendszeresen falutakarításokat szervez. A faültetési program is jellemző válasz volt. Többen aktív természetvédelmi programot is megneveztek, mint például a békamentés, vagy az erdőkben megjelenö tájidegen, illetve invaziv növényfajok célzott gyérítése. Üzemlátogatásokat is említettek néhány esetben, például szennyvíztisztító telep és hulladéklerakó meglátogatását.

Fontosnak tartjuk azt megjegyezni, hogy a terepi munka során szerzett tapasztalatok olyan érzelmi hatásokkal vannak a diákokra, melyek segítik a tudatosítást és bevésődést két irányban is (Robina-Ramírez, Melodio \& McCallum, 2020), kulcsélményeket generálnak a diákokban. Egyrészt a természettel való egészséges és kellemes kapcsolat szeretetet és törődést válthat ki (Christou, 2018), másrészt a természet kizsákmányolásának tapasztalatai az együttérzést erősítik a környezet és az élőlények iránt (Luthans \& Youssef, 2007).

Alkalmaz-e Ön az óráin bármilyen módszert, vagy részt vesz-e iskolán belüli környezetvédelmi szemléletformáló programok szervezésében, megvalósításában?

Nincsen termé- Legalább egy terszettudományos szakja a pedagógusnak mészettudományos szakja van a pedagógusnak

1,73 2,41

83,82

14,45
92,77

4,82

\section{Alkalmaz-e Ön, vagy részt vesz-e iskolán kívüli környezetvédelmi szemléletformáló programok szerve- zésében, megvalósításában?}

\section{Nincsen termé- szettudományos szakja a pedagó- gusnak \\ Legalább egy ter- mészettudomá- nyos szakja van a pedagógusnak}

3,47 3,61

30,06 37,35
Nincs adat (\%)

Alkalmaz

(\%)

Nem alkalmaz

(\%)

66,47 59,04

Az iskolán belüli- és kivü̈li környezetvédelmi szemléletformálásban résztvevö pedagógusok százalékos eloszlása az alapján, hogy tanitanak-e legalább egy természettudományos tárgyat, vagy nem 
Megvizsgáltuk, van-e összefüggés aközötthogy a kérdőívet kitöltő pedagógusok végeznek-e, illetve részt vesznek-e iskolán belüli- és kívüli környezetvédelmi szemléletformálásban, illetve rendelkeznek-e legalább egy természettudományos tárgy felsőoktatási szintű ismeretével. (7. ábra) Erre azért volt szükség, mert azt feltételeztük, hogy ilyen ismeretekkel rendelkező tanárok nagyobb arányban alkalmaznak, illetve vesznek részt környezeti szemléletformálást célzó programokon. Az összehasonlításban természettudományos tárgynak tekintettük az alábbi tárgyakat: komplex természettudományok, biológia, földrajz, kémia, fizika, matematika, környezettan, környezetismeret és természetismeret. Nem tekintettük természettudományos tárgynak az ezen kívüli tárgyakat, és a tanítókat sem, mivel a legtöbb esetben nem derült ki, hogy tanítóként milyen tantárgyakat tanítanak.

Hipotézisünket az adatok alátámasztják, hiszen mind az iskolán belüli, mind pedig az iskolán kívüli programok alkalmazásában nagyobb a legalább egy természettudományos tárggyal rendelkező pedagógusok aránya. Ugyanakkor ez a különbség nem nevezhető jelentősnek. Iskolán belüli programokat 9\%-kal, míg iskolán kívüli programokat 7\%-kal több olyan pedagógus használ, aki magasabb szintű természettudományos ismeretekkel rendelkezik. Ezek alapján kijelenthető, hogy feltevésünk ezen felmérés alapján helyes volt, a természettudományos tárggyal rendelkező tanárok gyakrabban alkalmaznak tanóráikon vagy tanóráikon kívül környezetvédelmi szemléletformáló programokat, ugyanakkor a különbség nem jelentős.

Az eredmények alapján azt is leszögezhetjük, hogy azon pedagógusok, akik a nem választ jelölők több mint 100 esetben időhiány miatt nem szerveznek vagy vesznek részt efféle programon. Néhány esetben kifejtették, hogy a szaktanárok hiánya miatt jelentős az óraterhelésük, amely miatt nem jut idő hétvégi vagy délutáni program megszervezésére, lebonyolítására. Több válaszadó is kiemelte, hogy ezt nem tekinti feladatának, és sokan válaszolták azt is, hogy erőforráshiány miatt nem tudnak megvalósulni az ilyen jellegü kezdeményezések. Az erőforrás alatt érthetjük a humán erőforrást is, azaz nem találnának kísérőtanárt, akivel közösen garantálni tudnák a diákok biztonságát terepi körülmények között. Szervesen idekapcsolódik az anyagi erőforrások hiányának problémája is, hiszen a tanárok a legtöbb esetben ezen túlmunkáért nem kapnak fizetést - többen utaltak arra, hogy nem tartanák etikusnak, hogy a diákok fizessék ki az ő kirándulásuk költségeit. Sokan jelezték, hogy - véleményük szerint - nem rendelkeznek kellő tudással, illetve információval egy ilyen program lebonyolításához. Ez kisebb részben önkritikaként, de valójában inkább a tanító- és tanárképzés hiányosságaira való utalásként, sokszor valóban jogos kritikaként is értelmezhetjük. Határozottan kell kijelentenünk, hogy mind a környezeti tematika, mind a gyakorlati ismeretek biztosító terepi programok terén igen nagy szükség volna felsőoktatási képzések elmélyítésére. 


\section{További ötletek és lehetőségek a szemléletformáláshoz}

A környezeti neveléssel kapcsolatos ismeretátadás hatékonysága szorosan összefügg az oktatás módjával is. A már meglévő tudatossági szinttől függetlenül, a terepi munka erösíteni tudja a diákokban a környezettudatosságot, legyen az hulladékkezelést, vízkészlet-hasznosítást vagy más részterületet célzó program (Buldur et al., 2020).

Esettanulmányként érdemes vázlatosan bemutatni a Schools4energy kezdeményezést, amely egy olyan iskolákon belüli program, amely során az iskolák egymás közt versenyezve igyekeznek csökkenteni az iskolai energiafelhasználást. Egyik résztémája az Art4energy, egy művészeti verseny, mely során a kreativitás bővítése is cél, míg a Play4energy részprogram játékos foglalkozásokon keresztül segíti az energiatudatosság növelését. A versenyben szereplő iskolák átlagosan havi 4\%-kal csökkentették az üvegházgáz-kibocsátásukat, és 1122 euró/hó-val a közüzemi számlákat - természetesen iskolánként (Pietrapertosa et al., 2021).

Altina és munkatársai (2014) szerint a család jobb jövedelemszintje és a szülők magasabb iskolai végzettsége, a környezettudatosságra és a diákok aktivitására egyaránt pozitív hatású. Ezért lenne fontos az, hogy minden diák részt vehessen kulcsélményeket adó, szemléletformáló környezeti nevelési programokon, amivel anyagi hasznuk is lenne a megtakarításukból, azon túlmenően, hogy a Föld erőforrásaival is jobban tudnak gazdálkodni.

Kutatásunk igazolta, hogy nem csak külföldi jó gyakorlatok léteznek, de hazánkban is sokan vannak, akik valóban szívügyüknek tekintik a környezetért felelős személyiség kialakítását. A kutatás során létrejött adatbázisból kiemelhető néhány pozitív hazai példa, amely egy-egy tantárgyhoz kapcsolódóan értelmezhető egyfajta javaslatként is a környezetpedagógia gyakorlatban ültetése terén:

- magyar nyelv: A szövegértési feladatoknál a témához kapcsolódó irodalmak száma szinte végtelen, ami bevihető órára, de akár a központozás tanításánál is lehet fenntarthatósággal foglalkozó szövegeket vinni. Ikon, index, szimbólum témánál hasznos lehet az újrahasznosítással, illetve szelektív gyüjtéssel kapcsolatos jeleket példának bevinni, hogy ezáltal ne csak a jel fogalma, de maga a jelentés is rögzülhessen a diákokban.

- magyar irodalom: Tájversek elemzésénél össze lehet vetni különböző korok tájait, a természetességet az ember által alkotott nagyvárosi környezettel. Prózáknál, ahol a táj fontos szerepet játszik, el lehet kalandozni, hogy ma hogyan is nézhetnének ki a valóságban. Például hogyan nézne ki ma a sziget, amin Robinson Crusoe hajótörést szenved?

- idegen nyelv: Szöveg-, illetve hallásértési feladatok is adhatók a környezetvédelem témakörében a vitatémák mellett. Ezernyi egyéb mellett például David Attenborough számos filmje (illetve ezek részletei) használható jól a túlnépesedési problematika bemutatásától a természetvédelem témáján keresztül a megújuló energiaforrások témakörének felvillantásáig. 
- történelem: Megbeszélés, vita, esetleg tablókészítési feladatként megjelenhet a II. világháború, gazdasági válság, ipari forradalmak témakörénél, legkézenfekvőbb pedig a nagy földrajzi felfedezések korának vizsgálatakor.

- hit- és erkölcstan: Bármely vallásról legyen is szó, az élet védelme mindenhol fontos szerepet játszik. Ide kapcsolódik saját magunk, emberiségünk, és a körülöttünk lévő természeti környezet gondozása és felelősségteljes használata.

- természettudományos tantárgyak: Bízunk abban, hogy természettudományos tantárgyak esetében sokkal egyértelmúbbek ezek a kapcsolatok, hiszen ezen tárgyak éppen a természeti környezetünk megismerését célozzák. Ugyanakkor kiemelendő, hogy a korábban ismertetett módszerek, például: vita egy nagyüzem vagy bánya (esetleg atomerőmü) telepítéséről, ábra- és képelemzések egy adott szennyezésről vagy problémához köthetően, projektmódszerek hulladékcsökkentési projekt, vagy akár iskolazöldítési projekt, hír-és forrásfeldolgozások, esetlegesen akár telefonos applikációk bevonása is segítheti az élményszerủbb oktatást és a tudásuk elmélyítését.

\section{Összegzés}

A kérdőívet kitöltő pedagógusok túlnyomó többsége fontosnak tartja, hogy a tanóráin környezettudatosságra való nevelés és fenntarthatósági szemléletformálás is történjen. A szaktanárok néhány személyes példáján keresztül láthattuk, hogy valóban bármely szaktárgy keretein belül van lehetőség a környezetünkkel kapcsolatos szemlélet formálására. Ráadásul mindezek megvalósítására változatos munkaszervezési formákban, különböző módszerek alkalmazásával van lehetőség - a kitöltők 90\%-a alkalmaz efféle elemeket a tanítási óráin.

Szükség is van erre az aktivitásra, hiszen a diákokban - és sokszor akár önmagunkban is - tudatosítanunk kell, hogy az emberi boldogság nem áll összefüggésben az elfogyasztott erőforrások és energia mennyiségével (Nørgaard, 2013; Munkácsy, 2014). A fokozódó erőforrás- és környezeti válság közepette éppen ezért a környezettudatosság fokozását célzó szemléletformáló programok elengedhetetlenek.

Ugyanakkor az iskolán kívüli lehetőségeket csak a válaszadók 32,5\%-a alkalmazza, vagy alkalmazta eddigi oktatói munkája során. A legtöbb esetben ezek terepgyakorlat jellegü programok, tematikus táborok, szemétszedések, illetve gyárlátogatások. Azok a tanárok, akik nem alkalmaznak ilyen módszereket, elsősorban idő- és erőforráshiányra hivatkoznak, illetve többek szerint ez a jellegü programszervezés nem tartozik a feladataik közé.

Arra azonban, hogy megértsük az ökológiai összefüggéseket, kölcsönhatásokat, és a természettudományok különböző diszciplínáit egészben láthassuk, csak akkor van lehetőségünk, ha a természeti környezetünket a terepen 
figyeljük meg (Kohl, 1992). Napjainkban már számos elvi lehetőség áll a tanárok rendelkezésére, amelyek során iskolán kívüli terepi programokra vihetik a diákokat, ugyanakkor, hogy ez a gyakorlatban is megtörténjen, annak több akadálya is van. Problémaként felmerülhet, hogy sok kiváló programról nem is tudnak a pedagógusok, továbbá, hogy bizonyos eseményekhez hosszabb előkészület szükséges. És ezen a ponton válik rendszerszintűvé a probléma. Ameddig a pedagógusképzés nem készíti fel a hallgatókat az ilyen jellegű programok szervezésére, a gyakorló pedagógusok óraszáma magas, és ezáltal idő- és erőforráshiánnyal küzdenek, addig nem számíthatunk elörelépésre. Ameddig a pedagógusnak önköltségen és saját szabadidejében kell a terepi programokat lebonyolítania, addig sajnos csak egy szűk réteg teheti meg, hogy ilyen programokat szervez és valósít meg. Megoldást jelenthetne a terepi programok nagyobb mértékü támogatása, valamint a tanárok motiválása is - mind erkölcsi, mind anyagi szempontból. Ugyanis, lehetnek bármennyire is nagyszerüek a programok, ha azok az iskolán kívüli keretek között vannak, akkor mindenképpen plusz erőforrásokat fognak igényelni a pedagógusoktól.

Rendelkezzen a Nemzeti Alaptanterv éppen most akárhogyan is, kijelenthető, hogy világunk harmonikus fejlődéséhez elengedhetetlen a fenntarthatósági oktatás előmozdítása, és ebben kulcsszerepük van a pedagógusoknak, hiszen ők azok, akik a diákok szemléletét nap mint nap formálni tudják (Ocetkiewicz, 2017). Kiemelendő továbbá, hogy az osztályterem elhagyása hatalmas módszertani eszköztárat kínál a pedagógusok számára (Kövecsesné Gősi, 2015).

\section{Köszönetnyilvánítás}

A tanulmány az Innovációs és Technológiai Minisztérium ÚNKP-19-2 kódszámú Ưj Nemzeti Kiválóság Programjának szakmai támogatásával készült. A szerzők ezúton is köszönik a Székesfehérvár Megyei Jogú Város Önkormányzat közreműködését és a bírálók építő jellegű kritikáit, amelyek hozzájárultak az írás színvonalának emeléséhez.

\section{Irodalom}

Altin, A., Tecer, S., Tecer, L., Altin, S., \& Kahraman, B. F. (2014). Environmental Awareness Level of Secondary School Students: A Case Study in Balıkesir (Türkiye). Procedia - Social and Behavioral Sciences, 141, 1208-1214. https://doi.org/10.1016/j.sbspro.2014.05.207

Bella T., Hámori V., Kotschy B., Móri Á., Szontagh P., Szőke-Milinte E. \& Wölfling Zs. (2013). Útmutató a pedagógusok minősítési rendszeréhez. Oktatási Hivatal.

Bendell, J. (2018). Deep Adaptation: A Map for Navigating Climate Tragedy. https:// www.lifeworth.com/deepadaptation.pdf (2019. 12. 09.) 
Benson, M. H., \& Craig, R. K. (2014). The End of Sustainability. Society E Natural Resources, 27(7), 777-782.

https://doi.org/10.1080/08941920.2014.901467

Buldur, S., Bursal, M., Yalcin E. \& Nazan, Y., (2020). The impact of an outdoor education project on middle school students' perceptions and awareness of the renewable energy. Renewable and Sustainable Energy Reviews, 134, https://doi.org/10.1016/j.rser.2020.110364

Chi-chung Ko A., \& Chi-kin Lee J (2003). Teachers' Perceptions of Teaching Environmental Issues within the Science Curriculum: A Hong Kong Perspective. Journal of Science Education and Technology, 12(3), 187-204.

https://doi.org/10.1023/a:1025094122118

Christou, P.A. (2018). Exploring agape: tourists on the island of love, Tourism Management, 68, 13-22.

https://doi.org/10.1016/j.tourman.2018.02.015

Csenger L. (2015). A környezeti nevelés elmélete és gyakorlata. Képzés és Gyakorlat, 13(1-2), 181-194. http://epa.oszk.hu/02600/02641/00009/pdf/EPA02641_ kepzes_es_gyakorlat_2015_1-2_181-194.pdf (2020.12. 20.)

Forbes, C. T., \& Zint, M. (2010). Elementary Teachers' Beliefs About, Perceived Competencies for, and Reported Use of Scientific Inquiry to Promote Student Learning About and for the Environment, The Journal of Environmental Education, 42(1), 30-42.

https://doi.org/10.1080/00958961003674673

Foster, J. (2015). After Sustainability. Earthscan/Routledge.

Hamilton, C. (2015). Requiem for a Species. Earthscan.

Johnson, B. (2016). Zero waste home: The ulimate guide to simplifying your life by reducing your waste. Penguin Books Ltd.

Kahn, B. (2017). The Arctic Has Been Crazy Warm All Year. This Is What It Means for Sea Ice. www.climatecentral.org/news/arctic-crazy-warm-sea-ice-21599 (2020.01.07.)

Kohl Á. (1992). Előszó. In Kárász Imre (Ed.), Ember és környezete. Ökológiai és környezetvédelmi terepgyakorlatok. Nemzeti Szakképzési Intézet.

Kováts-Németh M. (2010). Az erdőpedagógiától a környezetpedagógiáig. Comenius Kiadó.

Kövecsesné Gősi, V. (2015). A környezeti nevelés gyakorlata az erdei iskolában. Hazánk Kiadó.

Luthans, F. \& Youssef, C.M. (2007). Emerging positive organizational behavior. Journal of Management, 33(3), 321-349.

https://doi.org/10.1177/0149206307300814.

Mogyorósi A. (2018). A világ népességének ökológiai lábnyoma. http://www. geopolitika.hu/hu/2018/09/03/a-vilag-nepessegenek-okologiai-labnyomainfografika/ (2020.10.26.) 
Munkácsy B. (2014, Ed.). A fenntartható energiagazdálkodás felé vezető út Erre van elöre! Vision 2040 Hungary 2.0. ELTE TTK. Környezet- és Tájföldrajzi Tanszék. Környezeti Nevelési Hálózat Országos Egyesület.

Nemzeti alaptanterv (2012). Magyar Közlöny, 66, 10635-10848.

Nemzeti alaptanterv (2020). Magyar Közlöny, 17, 290-447.

Nørgård, J. S. (2013). Happy degrowth through more amateur economy, Journal of Cleaner Production, 38, 61-70.

https://doi.org/10.1016/j.jclepro.2011.12.006

Ocetkiewicz, I. (2017). Renewable energy in education for sustainable development, The Polish experience, Renewable and Sustainable Energy Reviews, 80, 92-97.

OECD (2018). https://www.oecd.org/education/talis/TALIS2018_CN_HUN.pdf (2020.01.23.)

Oliver, M. C., \& Adkins, M. J. (2020). "Hot-headed” students? Scientific literacy, perceptions and awareness of climate change in 15-year olds across 54 countries. Energy Research E Social Science, 70.

https://doi.org/10.1016/j.erss.2020.101641

Pietrapertosa, F., Tancredi, M., Salvia, M., Proto, M., Pepe, A., Giordano, M., Afflitto, N., Sarricchio, G., Di Leo, S. \& Cosmi, C. (2021). An educational awareness program to reduce energy consumption in schools, Journal of Cleaner Production, 278 ,

https://doi.org/10.1016/j.jclepro.2020.123949

Poortinga, W., Spence, A., Whitmarsh, L., Capstick, S. \& Pidgeon, N. F. (2011). Uncertain climate: An investigation into public scepticism about anthropogenic climate change. Global Environmental Change, 21(3), 1015-1024.

https://doi.org/10.1016/j.gloenvcha.2011.03.001

Robina-Ramírez, R., Medina Merodio, J. A., \& McCallum, S. (2020). What role do emotions play in transforming students' environmental behaviour at school? Journal of Cleaner Production, 258, https://doi.org/10.1016/j.jclepro.2020.120638

Rockström, J., Steffen, W.\& Noone, K (2009). A safe operating space for humanity, Nature, 461, 472-475.

https://doi.org/10.1038/461472a

Watts, J. (2018). Arctic warming: scientists alarmed by 'crazy'; temperature rises. https://www.theguardian.com/environment/2018/feb/27/arctic-warmingscientistsalarmed-by-crazy-temperature-rises (2019. 11. 24.)

Wiebe, K., Lotze-Campen, H., Sands, R., Tabeau, A., van der Mensbrugghe, D., Biewald, A. \& Willenbockel, D. (2015). Climate change impacts on agriculture in 2050 under a range of plausible socioeconomic and emissions scenarios, Environmental Research Letters, 10(8), https://doi.org/10.1088/1748-9326/10/8/085010 
Yilmaz, S., Majcen, D., Heidari, M., Mahmoodi, J., Brosch, T., \& Patel, M. K. (2019). Analysis of the impact of energy efficiency labelling and potential changes on electricity demand reduction of white goods using a stock model: The case of Switzerland, Applied Energy, 239, 117-132.

https://doi.org/10.1016/j.apenergy.2019.01.137

Zrinszky L. (2002). Neveléselmélet. Műszaki Könyvkiadó. 


\section{Nagy, B., Persa, M. \& Munkácsy, B.}

\section{Attitudes to environmental awareness}

We are drifting into a deepening environmental crisis. Some of the problems can no longer be avoided, but teachers should play a very important role in reducing them. At the same time, any recognition in this respect does not shape equally our work and our perception of the possibilities of environmental and conservation attitudes related to the school. An online questionnaire survey was used to explore this situation, which was completed by 256 teachers in Hungary. The analysis revealed that the vast majority of the participants consider it important to develop attitudes to environmental awareness in their lessons. Through personal examples of teachers, it can be demonstrated that it is possible to improve environmental awareness in the framework of any subject. This is important for most participants and it is considered as an expectation from teachers. Ninety percent have already used these specific tasks in their classes, but only three out of ten have taken part in out-of-school programmes, as organizer or supporter. Those who do not use such methods justified it by indicating lack of time and resources. Some of them argued that organizing such „external” programmes is not their task. At the same time, the desk research has pointed out that extracurricular programmes help to put the theoretical knowledge into practice and gain key experiences that contribute greatly to shaping their approach.

Keywords: online questionnaire; environmental awareness; classroom training; outof-school programme; key experience 